\title{
KAJTÁR Istvánné
}

DoI: 10.15170/DIKE.2020.04.01.12

ny. könyvtáros

PTE Egyetemi Könyvtár

\section{Állam és polgára \\ Kajtár István szakirodalmi munkássága}

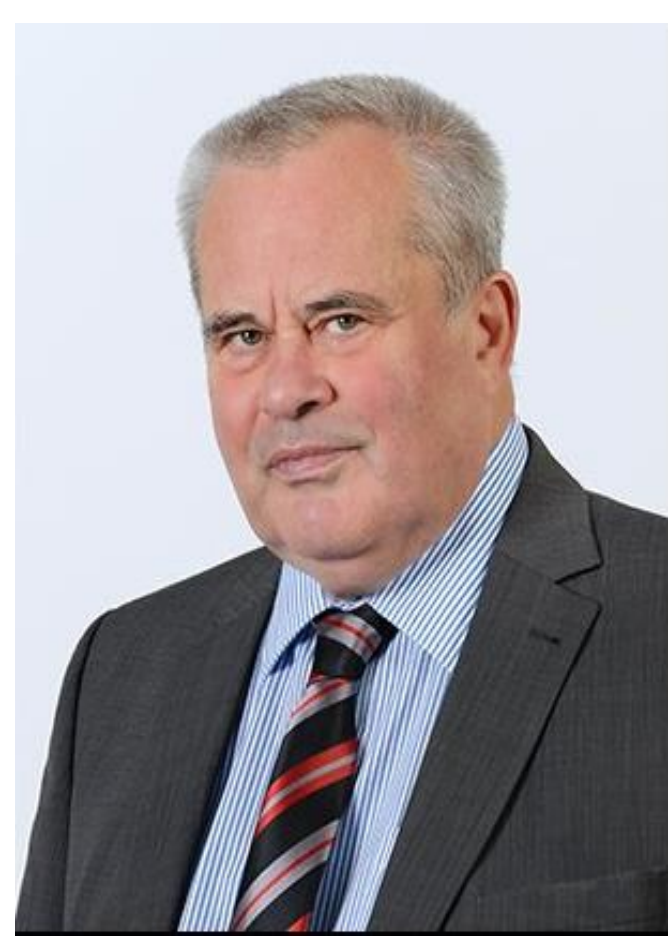

A most közreadott bibliográfia szerkezeti tagolását Kajtár István szövegeiből kiválasztott idézetekkel kívántam hangsúlyossá tenni, mondhatni katalogizálni. A kutatási területeket jelző felosztás természetesen átfedésekkel igaz, a címkék mégis eligazítanak, szándékom szerint érzelmi többletet is adnak.

Hivatásának megfelelően itt is első helyre került a jogtörténet tantárgy oktatása. Mindvégig hangsúlyos volt a joghistória haszna, az összehasonlító jogtörténet, a modernizáció, jogi transzfer kutatása. A legtöbb levéltári forrásfeltárást a közigazgatás-történet területén végezte.

Időközben írásaiba egyre inkább beleszövődött, majd vállaltan önálló kutatási területe lett a jogi kultúrtörténet a maga sokszínűségével. Az emberi és szakmai példaképül állítható elődök, a jogászképzés története, az egyetemtörténet megírása, megjelentetése mindvégig szívügye volt.

Intenzíven benne élt a „jogtörténész céh” történéseiben. A kollégák - beleértve az akadémiai berkeken kívülieket is - nagyrabecsülésének írásos lenyomata a recenziók sokasága. A korai évektől kezdve szívesen használt jogi probléma megvilágitásához a tengerek és hajók, a hadtörténelem, a haditechnika tárgykörből vett példákat. Később ezek nagyobb teret kaptak publikációi között is. A kalózkodásról, a tengeri zsákmányjogról, a cirkálókról vagy a hajóskapitányokról és a hajónevekről írt tanulmányok után tervbe vett írásának a Szevasztopol munkacímet adta.

Köszönet a Díké szerkesztőinek és e lapszám szerzőinek, hogy most ezen a módon lehet együtt szeretett „céhtársaival“. Nagyon kedvelte a szójátékokat, sokszor búcsúzott így, a szó elejét hangsúlyozva: Sz̧evasz̧topol. 
„A jogászképzés keretei kö̈zött az alkotmány-és jogtörténeti

elóadások egyfajta, hogy természettudományi hasonlattal

éjjünk, anatómiai és egyben élettani bevezetést nyújtanak."

2015 Egyetemes állam- és jogtörténet. 5. javított kiadás. Budapest (p. 414)

Társszerző: HeRGER Csabáné

2013 Egyetemes állam- és jogtörténet. 4. átdolgozott, bővített kiadás. Budapest - Pécs (p. 416)

Társszerző: HERGER Csabáné

2005 Egyetemes állam- és jogtörténet 3. átdolgozott kiadás. Pécs (p. 368)

2001 Egyetemes állam- és jogtörténet 2. kötet 2. változatlan kiadás. Pécs (p. 175)

2002 Egyetemes állam- és jogtörténet 2. kötet. Pécs (p. 175)

2000 Egyetemes állam- és jogtörténet 1. kötet. Pécs (p. 187) [utánnyomás]

1998 Egyetemes állam- és jogtörténet 2. kötet. Pécs (p. 176)

1997 Egyetemes állam- és jogtörténet 1. kötet. Pécs (p. 187)

1998 Grundzüge der ungarischenVerfassungsgeschichte. Pécs (p. 62)

1996 Általános jogtörténet 1. bővített, átdolgozott kiadás. Budapest (p. 503)

Társszerzők: HoRvÁTH Pál - NAGY Lászlóné - RÉvÉSZ T. Mihály - STIPTA István - ZLINSZKY János

1995 Általános jogtörténet. Budapest (p. 502)

Társszerzők: HORVÁTH Pál - NAGY Lászlóné - RÉVÉSZ T. Mihály - STIPTA István - ZLINSZKY János

1994 BRAUNEDER, Wilhelm: Osztrák alkotmánytörténet napjainkigkig. (=Österreichische Verfassungsgeschichte).

Fordította: KAJTÁR István. Pécs (p. 361)

1994 A Német-Római Birodalom állam- és jogfejlődése (VII. fejezet). In: HoRVÁTH Pál - RÉVÉSZ T. Mihály (szerk.):

Általános jogtörténet I. Budapest, 121-140.

1994 A német (osztrák) térség állam- és jogfejlődése 1806-1918. In: HORVÁTH Pál - RÉvÉSz T. Mihály (szerk.):

Általános jogtörténet I. Budapest, 305-326.

„A joghistória feltárhatja a hajdani jogrendszerek, jogintézmények, eljárási módok sikerének - kudarcának okait. (...) Ezek a megállapitások, értékelések, különösen a modern korszakra nézue jelentösek, és sajátos rezervoárt, ismeretanyagot, ,jogtörténeti génbankot" alkotnak."

2010 Über die Rechtsgeschichte und ihren Nutzen. In: MÁTHÉ Gábor - MEZEY Barna (szerk.): Das Wesen der Rechtsgeschichte: Werner Ogris zum 75. Geburstag. Budapest 41-51.

2006 Tanulmányok az 1956. évi forradalom és szabadságharc 50. évfordulójára. Pécs (p. 375) Társszerkesztők: ÁDÁM Antal - CSERESNYÉS Ferenc

2005 Jogtörténeti tanulmányok VIII. Pécs (p. 605) Társszerkesztők: BÉLI Gábor - SzEKERES Róbert

2001 Jogtörténeti tanulmányok VII. Pécs (p. 451) Társszerkesztő: SzEKERES Róbert

2001 Iura antiqua - iura moderna: Festschrift für Ferenc Benedek zum 75. Geburtstag. Pécs (p. 295)

Társszerkesztők: HAMZA Gábor - PÓKECZ KOVÁcs Attila - ZLINSZY János

1996 Tanulmányok Benedek Ferenc tiszteletére. Pécs (p. 323) Társszerkesztők: HAMZA Gábor - ZLINSZY János 


\section{„Polgári átalakulásunk, modernizációnk egy-egy szakasza sajátos állam- és jogformálási taktikát, technikát, következésképppen más és más értékeket közvetit."}

2003 A 19. századi modern magyar állam- és jogrendszer alapjai. Európa - haladás - Magyarország. Budapest - Pécs (p. 294)

2017 Charakterisieren der modernen ungarischen Rechtsentwicklung im 19. Jahrhundert. In: MáTHÉ Gábor (szerk.): Die Entwicklung der Verfassung und des Rechts in Ungarn. Budapest, 389-402.

2011 Alkotmányfejlo"désünk útjai: Válogatás Molnár Kálmán hátrahagyott írásaiból. Válogatta, jegyzetekkel kiegészítette: SCHWEITZER Gábor, szerkesztette: KAJTÁR István. Pécs (p. 200)

2006 Valahányszor e nemzet alkotmányos életfájára az irtó bárd nehezedett. In: ANDRÁssY György - NEMESSÁNYI Zoltán - VARGA Tamás (szerk.): Emlékkönyv Fülöp Miklós születésének ötvenedik évfordulójára. Pécs 130-144.

2005 Tradicionális jogi értékek - modern alkotmányos értékek. In: BÉLI Gábor - KAJTÁR István - SzEKERES Róbert (szerk.): Jogtörténeti tanulmányok VIII. Pécs, 225-241.

2005 Deák-vázlat egy jogászi habitushoz. In: SzABÓ István (szerk.): „,...a hazának szent ügye...”: Emlékülés Deák Ferenc születésének 200. évfordulója alkalmából. Budapest, 49-66.

2004 A magyar jogalkotás a XIX. században és tanulságai a XXI. századra nézve. In: SzEKERES Róbert (szerk.): Joghistória a 21. század elején: „Jog és jogászok a 21. század küszöbén“ nemzetközi konferencia (Pécs, 2003. október 16.) Pécs, 7-21.

2004 Traditionelle Wertordnung in Europa und die Wertordnung der Aufklärung in der Konstituirung der Staaten. In: SZEKERES Róbert (szerk.): Neuere rechtshistorische Arbeiten. Pécs, 3-11.

2004 Kossuth Lajos korának vezető rétegei: A kormányzati elit egyes kérdései a tizenkilencedik századi modernizáció során Közép- és Kelet-Európában. In: BALOGH Judit (szerk.): Európai Magyarországot! Kossuth Lajos és a modern állam koncepciója címú országos jogtörténeti konferencia tanulmányai (Debrecen, 2002. október 3-4.) Debrecen, 25-46.

2004 Hatalmi elitek a XIX. századi modernizációban. In: KORINEK László - KŐHALMI László - HeRKE Csongor (szerk.) Emlékkönyv Irk Albert egyetemi tanár születésének 120. évfordulójára. Pécs, 73-83.

2004 Gesetzgebung und Systemveränderungen. In: GEORGIEV, J. - KYSELE, J. (szerk.): Kapitoly z dĕjinstavovského a parlamentní hozřízení: Sborník příspěvku z 54. konference ICHRPI. Prága, 327-338.

2004 Deák und die Modenisierungsprozesse des 19. Jahrhunderts. In: MÁTHÉ Gábor - MEZEY Barna (szerk.): Nationalstaat - Monarchie - Mitteleuropa - zur Erinnerung an den „Advokaten der Nation”, Ferenc Deák. Budapest, 24-33.

2004 Deák és a 19. századi modernizációs folyamatok. In: SzABÓ András - BERTÓK Krisztina - KISTELEKI Károly (szerk.): A haza bölcse: Deák Ferenc. Budapest [CD-ROM]

2004 A polgári korszak igazságügy-miniszterei és az európai jogi kultúra. In: CSIBI Norbert - DoMANICZKY Endre (szerk.): Deák és utódai. Magyar igazságügyi miniszterek 1848/49-ben és a dualizmus korában: A Deákbicentenárium alkalmából rendezett országos történész-jogtörténész konferencia anyaga. Pécs 2004, 192-207.

2003 Deák és a 19. századi modernizációs folyamatok. In: SZABÓ András (szerk.): Deák Ferenc emlékezete. Budapest, 109-117.

2001 Európai jogi kultúra - magyar modernizáció a 19. században (büntetőjogi példákkal). In: TóTH Mihály Herke Csongor (szerk.): Tanulmányok dr. Földvári József professzor 75. születésnapja tiszteletére. Pécs, 128-138.

2001 1848-1849 és a XIX. századi modernizációnk. In: MEZEY Barna - VÖRÖS Imre (szerk.): A magyar polgári átalakulás alkotmányos forradalma: Jogtörténészek 1848-ról. Budapest, 207-218. 
2000 A 19. századi modern magyar állam- és jogrendszer alapjai: Tradíció - Európa - recepció. MTA doktori értekezés. Msc. (p. 209) (Disszertáció benyújtásának éve: 2000, fokozatszerzés éve: 2003)

2000 A magyar államiság első ezer éve. Pécs (p. 264) Társszerkesztő: FONT Márta

2000 Modernisierung in Ungarn im 19. Jahrhundert und die Staatsfinanzen anhand rechtshistorischer Beispiele. In: LINGELBACH, Gerhard (szerk.): Staatsfinanzen, Staatsverschuldung, Staatsbankrotte in der europäischen Staaten- und Rechtsgeschichte. Wien - Köln - Weimar, 185-190.

2000 Állam és jogfejlődés Magyarországon a 19. században. In: FONT Márta - KAJTÁR István (szerk.): A magyar államiság első ezer éve. Pécs, 177-196.

2000 A dualista kori magyar állam- és jogrendszer a modernizáció fényében. In: FISCHER Ferenc - MAJOROS István VONYÓ József (szerk.): Magyarország a (nagy)hatalmak erőterében: Tanulmányok Ormos Mária 70. születésnapjára. Pécs, 307-320.

1999 1848-49 és a XIX. századi modernizáció. Jogtudományi Közlöny 1999/5. sz. 193-199.

1998 A „konzervatív” és a „modern” a XIX. századi magyar jogtörténetben. In: BANA József (szerk.): Győri Tanulmányok. Győr, 52-58.

1997 Töredékek a XIX. századi magyar állam- és jogrendszer modernizációjához. Jura 1997/2. sz. 28-33.

1997 A magyar állam modernizációs folyamatai a XIX. században: kitekintéssel a XX. század első felére. Jogtudományi Közlöny 1997/3. sz. 126-129.

1996 A kereskedelmi jog történetének vázlata. Jogtudományi Közlöny 1996/10. sz. 404-414. Társszerző: SZÉCSÉNYI László

1996 A büntető igazságszolgáltatás modernizációja a XIX. században. In: KORINEK László (szerk.): Tanulmányok Földvári József tiszteletére. Pécs, 92-100.

1995 Modernizációnk és Európa: Adalékok a politikai vitakultúrához az 1843-44-es rendi országgyúlésen, In: MÁTHÉ Gábor - ZLINSZKY János (szerk.): Degré Alajos emlékkönyv. Budapest, 121-130.

1990 Rechtstheoretische und rechtshistorische Erläuterungen zur Effektivität des Rechts. Acta Juridica Academiae Scientiarum Hungaricae 1990/3-4. sz. 283-295. Társszerző: VISEGRÁDY Antal

1989 Rechtstheoretische und rechtshistorische Erläuterungen zur Effektivität des Rechts. In: TROJAN, Karel (szerk.): Efektivnost spolecenskeho pusoben i präva v prestavbe. Prága, 35-37. Társszerző: VISEGRÁDY Antal

1988 Jogtörténeti és jogelméleti adalékok a jog hatékonyságához. Jogtudományi Közlöny 1988/9. sz. 497-503.

Társszerző: VISEGRÁDY Antal

1986 Az államügyészség kiépítése Magyarországon a neoabszolutizmus idején. 1850-1854-1861. In: BENEDEK

Ferenc - SZITA jános (szerk.): Jogtörténeti tanulmányok VI. Budapest, 208-225.

„A modernizáció eszköztára a recepció, a jogátvétel, a

jogimport és a transzfer sokrétü alkalmazása volt."

2012 Rechts- und Gerichtspraxis in Ungarn 1840-1944: Tradition und Transfer. In: POKROVAC, Zoran (szerk.): Rechtssprechung in Osteuropa: Studien zum 19. und frühen 20. Jahrhundert. Frankfurt am Main,173-232. Társszerzők: BERKE Gyula - Herger Csabáné - KAJTÁr Edit - MÁZI András - NEMESSÁNYI Zoltán

2006 Modernizáció jogi transzferrel az európai kultúrában. Jogtörténeti Szemle 2006/3. sz. 70-73.

2003 Strafrechtsrezeption in Ungarn in dem 19. Jahrhundert. In: MEZEY Barna (szerk.): Strafrechtsgeschichte an der Grenze des nächsten Jahrtausendes. Budapest, 27-38.

2001 The Political Image of Europe in the Hungarian Parliament 1843-1913. (The extremities of a seventy-year-old process) In: HAMZA Gábor et al. (szerk): Iura antiqua - iura moderna: Festschrift für Ferenc Benedek zum 75. Geburtstag. Pécs, 131-139.

2001 Az újkori német jogi kultúra szakirodalma a Pécsi Püspöki Könyvtárban. Kitekintéssel a XIX. század közepéig. In: CSÓKA-JAKSA Helga (szerk.): A Klimo-könyvtár a tudományos kutatások szolgálatában. Pécs, 15-27. 
1989 Az osztrák jog magyarországi recepciójának kérdéséhez: Jogexport - adaptáció - jogi identitás. In: ÁDÁM Antal (szerk.): Tanulmányok Szamel Lajos tiszteletére. Pécs, 107-121.

1999 A magyar városok joga 1848-49-ben és az európai modernizáció. In: HoRVÁTH Attila (szerk.): Forradalom vagy reform? Tanulmányok az 1848/49-es forradalom és szabadságharc állam- és jogfejlődéséről. Budapest, $58-70$.

1998 Österreichisches Recht in Ungarn: Die Problemen der Rezeption und Identität während der Modernisation des Rechtssystems um die Mitte des 19. Jahrhunderts. In: PÉTER Orsolya Márta - SzABÓ Béla (szerk.): A bonis bona discere: Festgabe für János Zlinszky zum 70. Geburtstag. Miskolc, 451-472.

1998 Az osztrák (-német) büntető jogszabályok hatása a magyar jogban a 18. században. In: ÁDÁm Antal (szerk.): Dolgozatok az állam- és jogtudományok köréből XIX. Pécs, 29-64. Társzerző: BÉLI Gábor

1994 Österreichisches Strafrecht in Ungarn. Zeitschrift für Neuere Rechtsgeschichte 1994/4. sz. 325-334. Társzerző: BÉLI Gábor

1988 A burzsoá városigazgatás jogi rendjének kialakulása Európában és Magyarországon. In: MEZEY Barna (szerk.): Jogtörténeti előadások 1. Budapest, 85-99.

1987 A burzsoá városi jog kialakulása Közép- és Kelet-Európában. In: ÁDÁM Antal (szerk.): Dolgozatok az állam- és jogtudományok köréből XVIII. Pécs, 106-127.

1987 Die ungarische volksdemokratische Rechtssetzung (1945-1949). In: MALÝ, Karel (szerk.): Přispěvky k dějinám socialistické hostátu a práva I. Prága, 137-149.

\author{
„Az európai városok együtt születtek. Európával, és bizonyos \\ értelemben általuk sqületett meg Európa. Ha Európa mint \\ önálló történelmi egység létezike, ą talán leginkább a \\ városoknak kösqönhetőo."
}

1992 Magyar városi önkormányzatok (1848-1918). Területi és Települési Kutatások 9. Budapest (p. 212)

2010 A magyar városok jogtörténeti értékeiről. In: BALOGH Elemér - HOMOKI-NAGY Mária (szerk.): Emlékkönyv Dr. Ruszoly József egyetemi tanár 70. születésnapjára. Szeged, 435-444.

2008 Joghistóriai mozaikkövek a kormányzatról és a közszolgálatról. In: CSEFKÓ Ferenc (szerk.): Ünnepi kötet Ivancsics Imre egyetemi docens, decan emeritus 70. születésnapjára. Pécs, 19-27.

2008 Hegyközségek jogtörténeti szemmel. In: NAGY Janka Teodóra - SZABÓ Géza (szerk.): Vásárok Világa III. (Szekszárd, 2007. szeptember 15.). Szekszárd, 123-141.

2004 A polgári modernizáció közigazgatási autonómiáinak jogtörténeti keretei. In: GERGELY Jenő - STRAUSZ Péter ZACHAR Péter Krisztián (szerk.): Autonómiák Magyarországon 1848-1998. Budapest, 192-207.

2004 A magyarországi közszolgálat személyzete a XIX-XX. századi modernizáció során. In: KÉKI Zoltán (szerk.): Jogi beszélgetések 2000 - 2003. Kaposvár, 28-32.

2002 A magyar városigazgatás modernizációja a 19. században. In: HERTA Éva (szerk.): A kulturális térségek szerepe a regionális fejlesztésben. II. Székelyföld konferencia. Csíkszereda, 353-370.

2001 Községi önkormányzat és modernizáció a 19. századi Közép- és Kelet Európában: Kitekintéssel a 20. századra. Jura 2001/2. sz. 42-49.

2001 A modern községi közigazgatás kialakulása Közép- és Kelet-Európában a XIX. században. Comitatus: Önkormányzati Szemle 2001/10. sz. 61-68.

1999 A magyar városok joga 1848-49-ben és az európai modernizáció. In: HoRvÁTH Attila (szerk.): Forradalom vagy reform? Tanulmányok az 1848/49-es forradalom és szabadságharc állam- és jogfejlődéséről. Budapest, $58-70$.

1998 Az 1848: XXIII. törvénycikk a szabad királyi városokról és a modern városi önkormányzatok kialakulása Magyarországon. Debreceni Szemle 1998/3. sz. 440-445. 
1996 A modern magyar állam infrastruktúrájának kiépülése a XIX. században: A dél-dunántúli régió és Pécs példáján. In: VONYÓ József (szerk.): Az Előadások Pécs történetéből '94 és az Előadások Pécs történetéből '95 című konferenciák válogatott előadásai. Pécs, 23-30.

1996 A magyar közszolgálat. Közigazgatási szakemberképzés a XX. században. Budapest (p. 157) Társszerkesztők: BAKA András - LŐRINCZ Lajos - MÁTHÉ Gábor

1996 A közszolgálat személyzete 1919-1944. In: BAKA András - KAJTÁR István - LŐRINCZ Lajos - MÁTHÉ Gábor (szerk): A magyar közszolgálat. Közigazgatási szakemberképzés a XX. században. Budapest, 7-83.

1995 Városi önkormányzatok a 18-20. században a Dél-Dunántúlon. In: HoRVÁTH Gyula (szerk.): A Dunántúl szolgálatában: Előadások Rúzsás Lajos emlékének. Pécs, 67-84.

1994 Hungarian municipal governments (1848-1918). In: Annales Universitatis Scientiarum Budapestiensis de Rolando Eötvös nominatae. Sectioiuridica. Tom. XXXIV 1993. Budapest, 147-157.

1993 Zentralisation und Dezentralisation in der Rechtsgeschichte der ungarischen Selbstverwaltungen. In: MiKOLETZKY, Lorenz (szerk.): Bericht über den neunzehnten österreichischen Historikertag in Graz (18. - 23. Mai 1992). Wien 237-239.

1993 Újabb tendenciák az osztrák tartományok fejlődésében. Comitatus: Önkormányzati Szemle, 1993 3(1), $63-67$. 1993 A hegyközségi igazgatás története és a korábbi szabályozási modell adaptálásának lehetőségei. Msc. Pécs (p. 27) 1992 Kommunális Tudományok Dokumentációs Központja az osztrák községek szolgálatában. Comitatus: Önkormányzati Szemle 1992/11. sz. 79-80.

1992 Az osztrák tartományok Európa küszöbén. In: HRUBI László - KIss László - KÓBOR Gyula (szerk.): Európába megy-e a megye? Előadások és hozzászólások az 1992. szeptember 30 - október 2-i harkányi konferencián. Pécs, 166-168.

1991 Területi közigazgatás az Egyesült Európában. In: BELYÁCZ Iván et al. (szerk.): Európa '92: a Magyar Közgazdasági Társaság Baranya Megyei Szervezete, az MTA Jövőkutatási Bizottsága és a JPTE KJK által szervezett konferencia (Pécs, 1991. május 23-24.) előadásai. Ökonómia 1991/1. kötet. Pécs, 51-57.

1991 Szemere Bertalan és a városok reformja. In: RuszolyJózsef (szerk.): Szemere Bertalan és kora. Miskolc, 187-200.

1991 Development of the communal property in Hungary. In: HORVÁTH Gyula (szerk.): Regional policy and local governments. Pécs, 151-161

1990 Önkormányzati élet Pécsett (1848-1918). Baranya: Történelmi és honismereti folyóirat 1990/2. sz. 61-74.

1986 Übertretungen in den Statuten der Stadt Pécs in bourgeoisen Zeitalter. In: MÁTHÉ Gábor - RÉvÉSz T. Mihály (szerk.) A közigazgatási büntetőbíráskodás fejlődése az utolsó 100 évben. Tanulmánykötet. Entwicklung der Verwaltungsstrafgerichtsbarkeit in den vergangenen 100 Jahren. Sammelband. Igazságügyi Minisztérium Tudományos és Tájékoztatási Főosztály kiadványai 17. (Váltakozva német, francia és orosz nyelven). Budapest, 195-208.

1986 Az európai városjog fejlődése a feudalizmus idején és hatása a XIX. századi burzsoá városi jogra. In: ÁDÁM Antal (szerk.): Dolgozatok az állam- és jogtudományok köréből XVII. Pécs, 164-187.

1985 A községi tanácsi igazgatás stabilitásának kérdéséhez: Veszprém megye községei 1950 - 1981. Állam- és Igazgatás 1985/1. sz. 88-94.

1983 Pécs szabad királyi város választott polgárságának szószólója a rendiség utolsó évtizedeiben (1828-1848). In: CSIZMADIA Andor (szerk.): Jogtörténeti Tanulmányok V. Budapest, 115-127.

1983 Az egyes minisztériumok közötti koordináció kérdései. In: CsIZMADIA Andor: A kormányzás egyes kérdései a felszabadulás előtt. (A XI. fejezet, valamint a kimutatások anyagának levéltári kutatása és feldolgozása Kajtár István munkája). 341-360.

1982 A városigazgatás demokratizmusa Pécsett 1780-1848. In: SÁNDOR László (szerk.): Tanulmányok Pécs város történetéből: Pécs város szabad királyi rangra emelésének 200. évfordulója alkalmából rendezett II. várostörténeti konferencia előadásai. Pécs, 105-111.

1981 A nagybirtok befolyásának érvényesülése a helyi közigazgatásban a XIX-XX. századi Kelet- és KözépEurópában. Közigazgatásilag önálló uradalmak (Gutsbezirke, Gutsgebiete) II. rész. In: ÁDÁM Antal (szerk.): Dolgozatok az állam- és jogtudományok köréből XII. Pécs, 103-149. 
1980 A városi önkormányzat közigazgatásának társadalmi-, politikai és személyi környezete az Októberi Diploma időszakában. In: ÁDÁM Antal - BENEDEK Ferenc - SzITA János (szerk.): Jogtörténeti tanulmányok: Emlékkönyv Csizmadia Andor hetvenedik születésnapjára. Pécs, 169-181.

1979 A nagybirtok befolyásának érvényesülése a helyi közigazgatásban a XIX-XX. századi Kelet- és KözépEurópában (Gutsbezirke, Gutsgebiete) I. rész. In: ÁDÁM Antal (szerk.): Dolgozatok az állam- és jogtudományok köréből X. Pécs, 89-130.

1978 Az önkormányzati jogalkotás történeti áttekintése. Msc. [Államigazgatási Szervezési Intézet] (p. 22)

1975 Pécs szabad királyi város tanácsának múködése 1848-49-ben. PTE Jogtörténeti Tanszék kiadványa 1. Pécs (p. $47+3$ melléklet)

1973 A közigazgatás rendezéséről szóló 1929. évi XXX. tc. végrehajtása Pécsett. Msc. Pécs (p. 43)

$$
\begin{aligned}
& \text { „A jogi kultúrtörténet kutatási terrénuma vázlatosan leirható } \\
& \text { egymást metsðö köröke kö̃ös területével, ahol az egyes } \\
& \text { tudományterületek között sajátos kölcsönhatás érvényesül.” }
\end{aligned}
$$

2004 Bevezetés a jogi kultúrtörténetbe. Pécs (p. 156)

2018 Áttekintő értékelés a jogi kultúrtörténet forrásairól, módszertani és elméleti kérdéseiről, eredményeiről. In: NAGY Janka Teodóra (szerk.): A jogtörténet új forrásai: Jogi kultúrtörténeti és jogi néprajzi digitális adattár. Szekszárd, 205-249

2016 Szakrális elemek a jogi kultúrtörténetben. In: NAGY Janka Teodóra (szerk.): Szokásjog és jogszokás I-II. Jogi kultúrtörténeti és jogi néprajzi tanulmányok. Szekszárd, 196-203.

2014 A jogi kultúrtörténet a Pécsi Műhelyben. In: NAgY Janka Teodóra (szerk.): Tanulmányok Tárkány Szücs Ernő születésének 90. évfordulója tiszteletére. Szekszárd, 57-63.

2011 Institutions of Legal History with special regard to Legal Culture and History. Bratislava - Pécs (p. 464) Társszerkesztők: BÉLI Gábor - DuCHOŇOVÁ, Diana - FundÁRKOVÁ, Anna - PERES Zsuzsanna

2011 Hegyközségek bora. In: MEZEY Barna (szerk.): Bor és jogtörténet. Budapest, 16-33.

2009 Jogi kultúrtörténeti szövegek a tradíció és a modern határán. In: MEZEY Barna - NAGY Janka Teodóra (szerk.): Jogi néprajz - jogi kultúrtörténet: Tanulmányok a jogtudományok, a néprajztudományok és a történettudományok köréből. Budapest, 47-62.

2009 A szőlőskertek (jogi) kultúrtörténeti dicsérete. In: KOKOVAI Szabina - POHÁNKA Éva (szerk.): Ünnepi tanulmányok Móró Mária Anna tiszteletére. Pécs, 137-145.

2007 Über das Symbolsystem der ungarischen Revolutionen und Freiheitskämpfe. In: HERGER Csabáné et al. (szerk.): Recht ohne Grenzen. Festschrift zum 15. Jubilem der Zusammenarbeit der Grazer und Pécser Rechtshistoriker. Pécs 2007, 49-62.

2007 Der Adler als Machtsymbol. In: STEPPAN, Marcus - GEBHARTDT, Helmut (szerk.): Zur Geschichte des Rechts. Festschrift für Gernot Kocher zum 65. Geburtstag. Graz, 197-204.

2007 Állami ceremóniák és rítusok a dualizmus korában. Jogtörténeti Szemle (Különszám) 2007, 5-15.

2007 A dualizmus jogi kultúrtörténeti lenyomatai. Jogtörténeti Szemle 2007/3. sz. 24-31.

2006 Jogi kultúra, jogi szimbólumok és rítusok. In: MEZEY Barna (szerk.): Jogi kultúra, processusok, rituálék és szimbólumok. Budapest, 130-145.

2006 A forradalmak és szabadságharcok jelképeiről. In: KAJTÁR István - ÁDÁM Antal - CSERESNYÉS Ferenc (szerk.): Tanulmányok az 1956. évi forradalom és szabadságharc 50. évfordulójára. Pécs, 217-227.

2003 Die Architektur des Parlamentarismus in der Rechtskulturgeschichte. In: COHN, Henry J. (szerk.): Parliaments, Estates\&Representation. Aldershot, 89-96. 
2002 Tradition und Reform: Politische Argumentation in den Jahrzehnten des ungarischen Reformzeitalters. In: MEZEY Barna - MÁTHÉ Gábor (szerk.): Von dem Vormärz bis zum 20. Jahrhundert: Tradition und Erneuerung in der ungarischen Rechtsentwicklung. Budapest - Würzburg, 12-28.

2002 Die Grundzüge der Rechtskulturgeschichte in Ungarnum die Jahrtausendwende. In: VALENTINITSCH, Helfried - STEPPAN, Markus (szerk.): Festschrift für Gernot Kocher zum 60. Geburtstag. Graz, 130-147.

2002 Architektúra a jogi kultúrtörténetben. Jura 2002/2. sz. 35-44.

2001 Kérvénykultúránk jogtörténeti gyökerei. Jura 2001/1. sz. 123-127.

2001 Europäische Rechtskultur im ungarischen Parlament des 19. Jahrhunderts. In: MEZEY Barna - MÁTHÉ Gábor (szerk.): Von den Ständeversammlungen bis zum Parlamentarischen Regierungssystem in Ungarn. Studien zur Paralamentarismusgeschichte. Budapest - Graz, 17-24.

2000 A jog kulturális holdudvara. Iskolakultúra: Pedagógusok szakmai-tudományos folyóirata 2000/1. sz. 3-8.

1999 Jogi kultúrtörténet: Kurzusdokumentáció, szöveg-és képgyűjtemény. Pécs (p. 114)

1999 A jogi kultúrtörténet vizuális néprajzi forrásai. ÚJ Dunatáj: Tudományos és Mủvészeti Szemle 1999/2. sz. 68-71. Társszerző: NAGY Jaka Teodóra

1998 Ikonográfia - ikonológia: Előétel jövendő jogászok és jogtörténészek számára. Jura 1998/1. sz. 1-4.

1997 Adalékok a XIX. századi magyar politikai kultúrához: Modernizáció és politizálás. In: HORVÁTH Csaba (szerk.): Konfliktus, konszenzus, kooperáció II. Pécs, 146-155.

1996 Jogi stílusunk kultúrtörténeti gyökereiről. In: HAMZA Gábor - KAJTÁR István - ZLINSZKY János (szerk.): Tanulmányok Benedek Ferenc tiszteletére. Pécs, 124-132.

1996 Az önkormányzatok története és kultúrtörténete. In: KÉKI Zoltán (szerk.): Jogi beszélgetések 1993 - 1996. Kaposvár, 25-31.

1996 A pécsi városi önkormányzat kultúrtörténete a 19-20. században. In: VONYÓ József (szerk.): Az Előadások Pécs történetéből '94 és az Előadások Pécs történetéből '95 című konferenciák válogatott előadásai. Pécs, 333-336.

1994 Egy hatalmi jelkép kultúrtörténeti gyökerei: A sas. Jura 1994/1. sz. 11-17.

1986 Méltóságod lábainál azért hullok térdre. In: KENGYEL Miklós (szerk.): Studia Juvenum: Seria Juridica III. Pécs 69-81.

1982 A Népköztársaság nevében: Adalékok az ítéleti praeambulumhoz. Jogtudományi Közlöny 1982/1. sz. 34-37. Társszerző: KENGYEL Miklós

\section{„Nur die Persönlichkeit! - Jogtudó értelmiség, nagy elödök a jogászképzésben}

2013 Gernot Kocher [Antológia]. Szerkesztette, fordította: HERGER Csabáné. A fordítást az eredetivel összevetette KAJTÁR István. Budapest - Pécs (VIP kiskönyvtár; Európai jogtörténészportrék 2.) (p. 105)

2013 Jogtörténeti Tanszék. In: ÁDÁM Antal (szerk.): A pécsi jogi kar 90 éve. Pécs, 117-134.

2011 Juristen und Juristenausbildung 1919-1944 in Ungarn. Krakowskie Studia z Historii Panstwa i Prawa 2011/4. sz. 77-86.

2010 Prof. Andor Csizmadia Dr. Dr. h. c. and his research into the legal history of dualism. In: BARAN, Kazimierz (szerk.): Constitutional Developments of the Habsburg Empire in the Last Decades before its Fall: The materials of Polish-Hungarian Conference (Cracow, September 2007). Krakkó, 45-50.

2009 „Papi talárján a tudós palástja, az egyik kezében a mise-, a másikban a törvénykönyv”: Dr. Késmárky István jogakadémiai igazgató, jogi kari dékán. In: KAJTÁR István - POHÁNKA Éva (szerk.): A Pécsi Püspöki Joglyceum emlékezete 1833 - 1923. A 2009. október 16-án Pécsett tartott tudományos konferencia tanulmányai. Pécs, 89-104.

2009 A Pécsi Püspöki Joglyceum emlékezete 1833-1923: A 2009. október 16-án Pécsett tartott tudományos konferencia tanulmányai. Pécs (p. 313), társszerkesztő: POHÁNKA Éva 
2007 Werner Ogris [Antológia]. Fordította: HERGER Csabáné, válogatta: KAJTÁR István. Budapest - Pécs (VIP kiskönyvtár, Európai jogtörténészportrék 1.) (p. 182)

2007 Rechthistoriker in Graz und Pécs - eine fruchtbringende Kooperation. In: HERGER Csabáné et al. (szerk.): Recht ohne Grenzen: Festschrift zum 15. Jubilem der Zusammenarbeit der Grazer und Pécser Rechtshistoriker. Pécs, 9.

2005 Rechtsgeschichte: Gedanken für Gegenwart und Zukunft. In: SZEKERES Róbert (szerk.): Rechtsgeschichte: Gedanken für Gegenwart und Zukunft. Pécs, 5.

2004 Die freundschaftliche Beziehung der Rechtshistoriker von Graz und Pécs. In: SzEKERES Róbert (szerk.): Neuere rechtshistorische Arbeiten. Pécs, 1-2.

2003 A Pécsi Állam- és Jogtudományi Kar története (1923-2002). In: TAKÁcs Péter (szerk.): A jogászképzés múltja, jelene és jövője. Ünnepi tanulmányok, konferencia-előadások, kerekasztal-beszélgetések. Budapest, 226-230.

2001 A pécsi egyetemi szintű jogászképzés története. Jura 2000/1-2. sz. 121-124.

2001 Widmung. In: HAMZA Gábor et al. (szerk.): Iura antiqua - iura moderna: Festschrift für Ferenc Benedek zum 75. Geburtstag. Pécs, 7-10. Társszerzők: PÓKECZ KovÁcs Attila - BESSENYŐ András

2001 Holub József (1885-1962). In: HAMzA Gábor (szerk.): Magyar jogtudósok II. Budapest, 119-128.

2001 Csizmadia Andor (1910-1985). In: HAMZA Gábor (szerk.) Magyar jogtudósok II. Budapest, 177-188.

2001 A pécsi joghistóriai múhelyek a huszadik században. In: KAJTÁR István - SZEKERES Róbert (szerk.): Jogtörténeti tanulmányok VII. Pécs, 229-251.

2000 Jog és iskola. Iskolakultúra: Pedagógusok szakmai-tudományos folyóirata 2000/2. sz. 71-83.

2000 A Jogi Kar professzorai. In: CZIBÓK Balázs - JANKOVITS László - NAGY Ferencné (szerk.): Memoria professorum Quinqueecclesiensium. Pécs, 39-58.

1999 A pécsi jogászképzés története. Magyar Jog 1999/2. sz. 94-96.

1997 A pécsi jogászprofesszorok emlékezete 1921-1945. In: NAGY Ferencné (szerk.): Per aspera ad astra.

Megemlékezés a honfoglalás 1100. és az Erzsébet Tudományegyem Pécsre költözésének 75. évfordulójáról. Pécs, 61-66.

1996 Az életpálya. In: HAMZA Gábor - KAJTÁR István - ZLINSZKY János (szerk.): Tanulmányok Benedek Ferenc tiszteletére. Pécs, 1-4.

1992 A Janus Pannonius Tudományegyetem Állam- és Jogtudományi Karának krónikája 1990-1991. Pécs (p. 20) 1991 A Janus Pannonius Tudományegyetem Állam- és Jogtudományi Karának krónikája 1989-1990. Pécs (p. 20) 1990 A Janus Pannonius Tudományegyetem Állam- és Jogtudományi Karának krónikája 1988-1989. Pécs (p. 16) 1989 A Janus Pannonius Tudományegyetem Állam- és Jogtudományi Karának krónikája 1987-1988. Pécs (p. 18)

1975 Pécsi jogi képzés változása 1945-1948 között: Különös tekintettel ennek a jogtudat alakulására gyakorolt hatására. Msc. Kutatási jelentés (p. 46)

\section{„Master next God” - a kapitány, azaz az egymást követó korok hajöit a hajódeszkékon állva irányitó tekintély}

2016 Tengeralattjárók. In: BIRó Zsófia - JuszTingER János - PÓKECZ KOVÁCs Attila (szerk.): Antecessores Iuris Romani. Óriás Nándor és Benedek Ferenc emlékezete: Tanulmányok a római jog és a jogtörténet köréből. Pécs, 217-232.

2014 Lepanto, 1571. október 7. In: BENE Krisztián - DÁVID Ferenc - SARLÓs István (szerk.): Válogatás a Hadtörténeti esték 2006 és 2014 között elhangzott előadásaiból. Fejezetek a hadtörténelembõl 3. Budapest Pécs, 139-162.

2014 A hajóparancsnok státusza, büntetőjogi felelőssége. Jogtörténeti elemzés. In: KŐHALMI László - GÁL István László et al. (szerk.): Tanulmányok Bodnár Imre egyetemi adjunktus tiszteletére. Emlékkötet. Pécs, 241-247.

2013 Az antik görögök tengeri háborúi a Kr. e. V. században. In: MÁTHÉ Gábor - RÉVÉsz T. Mihály - GOSZTONYI Gergely (szerk.): Jogtörténeti Parerga: Ünnepi Tanulmányok Mezey Barna 60. születésnapja tiszteletére. Budapest, 182-187. 
2011 Hadihajónevek a tengeri hatalom szimbólum rendszerében. In: MEZEY Barna (szerk.): A szimbólumok üzenete: a jogi kultúra jelképei: eljárások, szokások, formák és tárgyak. Budapest, 255-267.

2011 Az osztrák-magyar haditengerészet jelképeiről. In: BENE Krisztián - DÁvID Ferenc - SARLÓs István (szerk.): Válogatás a Hadtörténeti esték 2006 és 2010 között elhangzott előadásaiból. Fejezetek a hadtörténelemből 1. Pécs, 83-96.

2011 Der Schiffskommandant in der neueren Rechtgeschichte. In: BÉLI Gábor et al. (szerk.): Institutions of Legal History with special regard to Legal Culture and History. Bratislava - Pécs, 301-311.

2010 Imperial (and) royal glosses: In memoriam Géza Herczegh. In: BÉLI Gábor - Herger Csabáné - PERES Zsuzsanna (szerk.): Jogtörténeti Tanulmányok 10. Pécs, 83-96.

2007 A császári és királyi haditengerészet jelképei - jogtörténeti háttérrel. Jura 2007/2. sz. 184-188.

2006 A magyar tengerjog matuzsálemei: Az Editto politico di navigazione mercantile (1774) és a Code de Commerce II. Du commerce maritime (1807). In: MEZEY Barna - RÉVÉSZ T. Mihály (szerk.): Ünnepi tanulmányok Máthé Gábor 65. születésnapja tiszteletére. Budapest, 225-245.

2005 Machtsymbole auf der See. Ein geschichtlicher Beitrag zur Namengebung der Kriegsschiffe. In: SZEKERES Róbert (szerk.): Rechtsgeschichte: Gedanken für Gegenwart und Zukunft. Pécs, 46-67.

2004 A Mediterránum (sic!) tengerjogának történetéhez: Török szultáni fermán. Jogtörténeti Szemle 2004/4. sz. 71-77.

2000 A tengeri zsákmányjogról. Tudományos Dialóg 1. Jogtörténeti különszám 7-14.

1999 Német segédcirkálók a második világháborúban: A tengeri kaméleonok. Rubicon 1999/5-6. sz. 82-83.

1997 „C. S. S. Alabama.” Adalék tengeri háborúk jogtörténetéhez. Jura 1997/1. sz. 14-20.

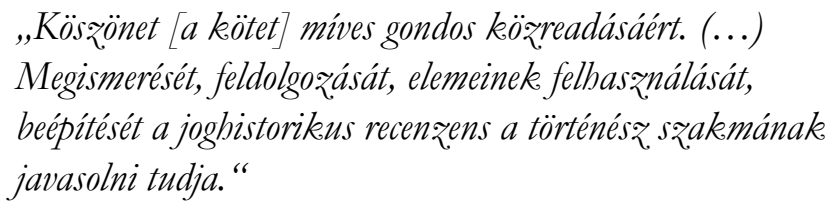

2013 Anatol Schmied-Kowarzik, Unteilbar oder untrennbar? Die Verhandlungen zwischen Cislejthanien und Ungarn zum gescheiterten Wirtschaftsausgleich 1897. Südost-Forschungen 72. 453-456. Társszerző: HergER Csabáné

2013 A hatalommegosztás államszervezete: gondolatok egy minap megjelent magyar alkotmány- és közigazgatástörténeti egyetemi jegyzet kapcsán: [Bódiné Beliznai Kinga, Gosztonyi Gergely, Horváth Attila, Képes György, Mezey Barna, Völgyesi Levente: Magyar alkotmány- és közigazgatás-történet a polgári korban: a hatalommegosztás államszervezete, 1848-1949. Szerk. Képes György. ELTE Jogi Kari Jegyzetek 9. Budapest: ELTE Eötvös Kiadó, 2013. 234 p.] Jogtörténeti Szemle 2013/2. sz. 54-56.

2012 Az osztrák minisztertanács protokolumai 1850 október - 1851 május. Jura 2012/1. sz. 254-255.

2012 A fenyítőházak forradalma - Mezey Barna monográfiájáról: [MEZEY Barna: A fenyítőházak forradalma: a modern büntetés-végrehajtás alapvetése Európában. Budapest 2012, 540 p. Jogtörténeti Szemle 2012/4. sz. $51-54$.

2011 Új monográfia Bosznia-Hercegovina közjogtörténetéről: Szabó Szilárd könyvéről. Jogtörténeti Szemle 2011/4. sz. $73-75$.

2011 Osztrák minisztertanácsi jegyzőkönyvek 1850 október - 1851 május. Jogtörténeti Szemle 2011/2. sz. 64-65.

2011 Nagymonográfia Ausztria államszervezetéről (1918-1955) - Szabó István. Jogtörténeti Szemle 2011/1. sz. 64.

2011 Grundlagen der österreichischen Rechtskultur. Festschrift für Werner Ogris zum 75. Geburtstag. Jura 2011/2. sz. 257-260. Társszerző: HeRGER Csabáné

2009 Osztrák minisztertanácsi jegyzőkönyvek az Októberi Diploma kiadását követő hónapokból. Jura 2009/2. sz. 238-239. 
2009 Az Osztrák Császárság kormányzata hatalompolitikai kurzusváltás előtt. (Die Protokolle des österreichischen Ministerrates 1848-1867. IV. Abteilung. Das Ministerium Rechberg. Band 2. 6. März 1860 - 16. Oktober. Wien 2007) Jura 2009/1. sz. 236-237.

2009 A népi jogéletről Makón (1781-1821): Nagy Janka Teodóra: Jogélet a két „vész” között. Jura 2009/1. sz. 238-239.

2008 Jogtörténeti munka a 19. század végi magyar igazságszolgáltatási reformokról. (Antal Tamás: Törvénykezési reformok Magyarországon (1890-1900) Szeged, 2006). Jura 2008/1. sz. 225-226.

2008 Az osztrák nagypolitika irányváltás előtt (1860): (Die Protokolle des österreichischen Ministerrates 18481867. IV. Abt. Das Ministerium Rechberg. Band 2. Wien, 2007). Jogtörténeti Szemle 2008/4. sz. 48-49.

2007 Ruszoly József: Európa alkotmánytörténete. Dialógus 2007/10. sz. 26-27.

2007 A Schwarzenberg minisztérium jegyzőkönyvei az 1850-es esztendő derekáról. (Die Protokolle des österreichischen Ministerrates 1848-1867. II. Abt. Das Ministerium Schwarzenberg. Band 3. 1. Mai 1850 - 30. September 1850. Wien 2006 XLII +361 o.) Jura 2007/2. sz. 215-216.

2007 A Schwarzenberg minisztérium jegyzőkönyvei 1850 elejéről. (Die Protokolle des österreichischen Ministerrates1848-1867: II. Abt.: Das Ministerium Schwarzenberg, Band 2. 8. Jänner 1850 - 30. April 1850) Jogtörténeti Szemle 2007/2. sz. 58-59.

2006 Históriai-joghistóriai kötetek déli szomszédállamaink ismeretéhez. (HEKA László: A magyar-horvát államközösség alkotmány- és jogtörténete 2004; Horvátország kulturális és művészettörténete: Bevezetés a kroasztikába 2004; Szerbia állam- és jogtörténete 2005). Jura 2006/2. sz. 135-136.

2006 A Szász tükör: (Eike von Repgow: A Szász tükör. Közreadja: BLAzOvich László - SCHMIDT József, Szeged 2005). Jogtörténeti Szemle 2006/2. sz. 93-94.

2005 Szegedi jogászprofeszoroknak szentelt emlékkönyvekről. Dialógus 2005/8. sz. 54-62.

2005 Szeged megyei jogú város közönségének! A Város és jogtörténésze. (RuSzOLY József: Szeged szabad királyi város törvényhatósága 1872-1944. Szeged 2004). Szeged: A város folyóirata 2005/2. sz. 34-35.

2004 Monográfia a térszerkezet mikroelemeinek összekapcsolásáról (SOMLYÓDYNÉ PFEIL Edit: Önkormányzati integráció és helyi közigazgatás). Magyar Tudomány 2004/12. sz. 1450-1452.

2004 Az osztrák kormányzat válságos időkben (Die Protokolle des österreichischen Ministerrates 1848 - 1867. IV. Abt. Das Ministerium Rechberg. Bd. L. 19. Mai 1858 - 2/3. März 1860). Jura 2004/1. sz. 183-184.

2004 A Habsburg-birodalom krízise és a modernizáció az osztrák minisztertanács jegyzőkönyveinek tükrében. 1848. december 5. - 1850. január 7. Jogtörténeti Szemle 2004/1. sz. 80-81.

2002 Új jogi néprajzi munka jelentkezik. (Nagy Janka Teodóra: A tradicionális népi önkormányzatok jogtörténeti vizsgálata a Dél-Dunántúlon). ÚJ Dunatáj 2002/3. sz. 32-36.

2001 A magyar országgyűlés történetének képeskönyve. Album a magyar joghistória kedvelőinek. Magyar Jog 2001/3. sz. 191.

2000 Pályaképek: Emlékkönyvek a szegedi jogi karról. Szeged: A város folyóirata 2000/2. sz. 23-25.

1999 Gernot Kocher: Zeichen und Symbole des Rechts. Eine historische Ikonographie. Ethnographia 1999/2. sz. 516-519. Társszerző: NAGY Janka Teodóra

1999 Modernizáció és magyar államiság. Forráskötet az osztrák-magyar kapcsolatok 19. századi történetéhez. (Die Protokolle des österreichischen Ministerrates 1848 - 1867, V. Abt. 9.) Jogtudományi Közlöny 1999/6. sz. 275-276.

1998 Jogtörténeti útikönyv Bécsről. Jogtudományi Közlöny 1998/2. sz. 69-70.

1998 Gernot Kocher: Zeichen und Symbole des Rechts. Eine historische Ikonographie. ÚJ Dunatáj 1998/3. sz. 516519. Társszerző: NAGY Janka Teodóra

19971848 az osztrák minisztertanács jegyzőkönyveinek tükrében. (Die Protokolle des österreichischen Ministerrates 1848-1867. I. Abt. Die Ministerien des Revolutionsjahres 1848. 20. März 1848 - 21. November 1848). Jura 1997/2. sz. 47-49.

1996 Kormányzati politika - egykorú minisztertanácsi jegyzőkönyvek tükrében. Magyar Közigazgatás 1996/2. sz. 111-112.

1995 A „Régiók Európája” sorozat első kötete (Régiók és városok az olasz modernizációban. Szerk. HoRVÁTH Gyula. MTA RKK, Pécs 1993). Magyar Közigazgatás 1995/2. sz. 126-128. 
1994 Útikalauz az Osztrák Császárság kormányzattörténetéhez. (Die Protokoile des österreichischen Ministerrates 1848-1867. V. Abt. Die Ministerien Erzherzog Rainer und Mensdorff. Band 7. 15. Oktober 1863 - 23. Mai 1864). Jura 1994/2. sz. 50-52.

1994 Palotás város: Gondolatok a Szeged története III. kötetéről (Szeged 1991). Jura 1994/1-2. sz. 149-151.

1992 Kormányzattörténeti alapforrás a 19. századi osztrák és magyar jogtörténethez (Die Protokolle des österreichischen Ministerrates 1848-1867). Jogtörténeti Szemle 1992/2. sz. 68-69.

1991 A magyar helyi önkormányzatok időtálló történelmi hagyományaiból. Győri tanulmányok 1991/1. Fejezetek a győri önkormányzatok történelméből. Szerk. LADOS Mihály). Magyar Közigazgatás 1991/11. sz. 1054-1056.

1989 Egy hivatás felkészülése az új Európára. Jogászképzés az ezredfordulón. („Das Rechtsstudium für das Europa von morgen“ szimpóziumról. Bécs, 1989. május 24.) Jogtudományi Közlöny 1989/10. sz. 549-551.

1987 Arcképek Közép-Európa jogászrendjének történetéből (Juristen in Österreich 1200-1980). Jura 1995/1. sz. $27-28$.

1985 Ruszoly József: A szegedi népképviseleti közgyúlés 1848-1871. Állam- és Igazgatás 1985/11. sz. 1052-1053.

1984 Csizmadia - Máthé - Nagy: Magyar közigazgatástörténet: kézikönyv levéltárosok használatára. Levéltári Szemle 1984/1-3. sz. 391-393.

1984 Új archontológiai kiadvány (Fejes Imre: Veszprém megye közigazgatási beosztásai és tanácsi vezetői, 19451950-1982). Levéltári Szemle 1984/1-3. sz. 387-389.

1984 Nemzetközi Közigazgatás- és Jogtörténeti Konferencia. Állam- és Igazgatás 1984/3. sz. 277-279.

1984 A „Magyar Közigazgatástörténet” jegyzet vitája. Állam- és Igazgatás 1984/6. sz. 564-566.

1983 Ruszoly József: A választási bíráskodás Magyarországon 1847/1948. Jogtudományi Közlöny 1983/12. sz. 775-777.

1982 Tanulmányok Baranya megye ifjúsági mozgalmának történetéből 1868-1950. Levéltári Szemle 1982/2-3. sz. 445-447.

1982 Közigazgatási reform Magyarországon a török kiűzése után. Könyv az Einrichtungswerkről. Jogtudományi Közlöny 1982/3. sz. 227-228.

1981 Tanulmányok Csongrád megye történetéből: 19. század. Somogyi-Könyvtári Múhely 1981/1. sz. 49-50.

1981 Szegedi joghallgatók államtudományi dolgozatai 1-2. köt. Szeged, 1976-1979. Állam- és Igazgatás 1981/2. sz. 189-190.

1979 Közigazgatástörténeti kerekasztal-konferencia. Jogtudományi Közlöny 1979/11. sz. 773.

1978 A szegedi „Acta Iuvenum” új sorozatának első kötete. Jogtudományi Közlöny 1978/7. sz. 439-440.

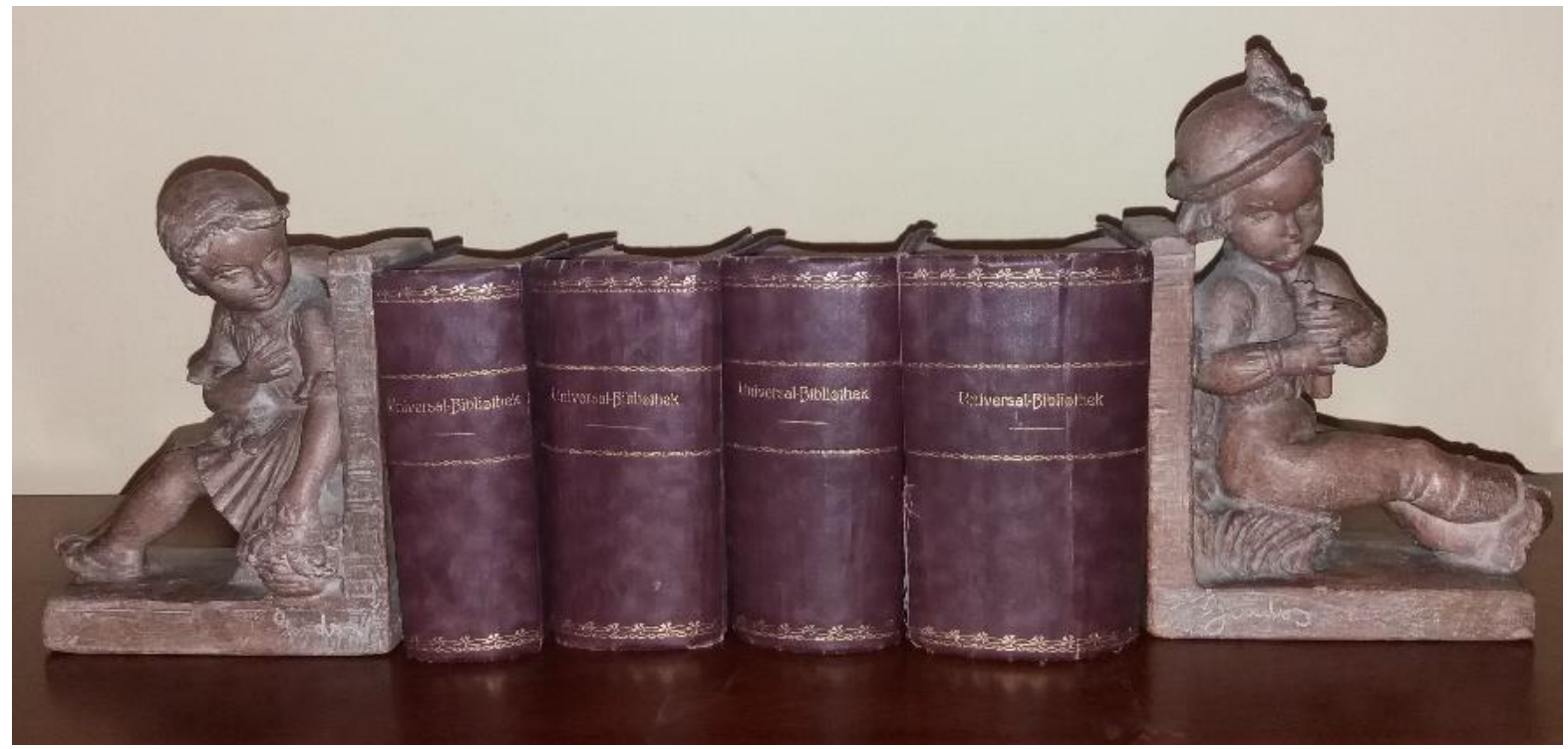

Könyvtámasz a családi könyvtárban. Forrás: Kajtár Istvánné 